\title{
Analitičke dimenzije za istraživanje transnacionalnih aktivnosti: primjer kineskih migranata u Hrvatskoj
}

\author{
Simona KUTI \\ Institut za migracije i narodnosti, Zagreb \\ simona.kuti@imin.hr \\ Saša BOŽıć \\ Odjel za sociologiju, Sveučilište u Zadru \\ sbozic@unizd.hr
}

\begin{abstract}
Koncept transnacionalnih socijalnih prostora polako zamjenjuje koncept transnacionalizma, koji se kritizira zbog promašenosti termina, konceptualne nejasnosti, nemogućnosti određivanja granica fenomena kojim se bavi i sl. Usprkos tome, samo neki slučajevi migrantskih transnacionalnih veza prerastaju u transnacionalne socijalne prostore, koje je vrlo teško istraživati s ograničenim sredstvima i brojem istraživača jer zahtijevaju kontinuirano i sinkronizirano praćenje svakodnevnih praksi u više međunarodnih lokaliteta. Stoga je odabir analiziranja migrantskih transnacionalnih aktivnosti kao i eventualna procjena njihove saturacije $\mathrm{i}$ intenziteta puno pouzdaniji postupak od pretpostavljanja, pa zatim potvrđivanja ili odbacivanja postojanja transnacionalnih socijalnih prostora $u$ određenom slučaju. U radu se prezentiraju rezultati istraživanja transnacionalnih aktivnosti kineskih migranata u Hrvatskoj metodom polustrukturiranih intervjua. Iz radova o migrantskom transnacionalizmu izdvojene su dimenzije i analitičke kategorije za istraživanje transnacionalnih aktivnosti, a rezultati su strukturirani prema sadržajnim sferama aktivnosti (ekonomske, socijalne, kulturne i političke transnacionalne aktivnosti). Objašnjavajuća moć i transferabilnost ustanovljenoga analitičkog modela, koji je dosad bio primjenjivan na druge migrantske skupine $\mathrm{u}$ drugim kontekstima, ocjenjuje se kroz prikaz transnacionalnih aktivnosti kineskih migranata u Hrvatskoj.
\end{abstract}

Ključne riječi: dimenzije transnacionalnih aktivnosti, transnacionalizam, kineski migranti, Hrvatska

\section{Uvod}

Istraživanja migracija, pogotovo unutar sociologije i antropologije, već gotovo dva desetljeća uključuju i dvojbeni koncept transnacionalizma. 
Usprkos neprikladnosti termina, nejasnosti samog koncepta (Božić, 2004) i nemogućnosti određivanja granica fenomena kojim se bavi, istraživanja transnacionalizma kao fenomena upućuju na važan oblik suvremenoga društvenog djelovanja - generiranje transnacionalnih veza i praksi različitih aktera, od individualnih i grupnih do institucionalnih. Sâm termin u većini migracijskih studija odnosi se na aktivnosti spontanih neinstitucionalnih aktera (Portes, 2001) koje transcendiraju granice nacija-država, stvaraju nove i koriste stare lojalnosti i pripadnosti izvan ograničavajućih okvira tzv. nacionalnih društava odnosno kontejner-društava. Autori naglašavaju da su se transnacionalne veze toliko osnažile i raširile da se u brojnim slučajevima već može govoriti o posve deteritorijaliziranim transnacionalnim socijalnim prostorima u kojima prakse umreženih, ali fizički udaljenih aktera u nekoliko međunarodnih lokacija, determiniraju svakodnevicu i pravac djelovanja svih povezanih aktera (Pries, 2001, 2008). Transnacionalne veze su iz ove perspektive toliko saturirane da njihov determinirajući učinak na svakodnevicu i praksu pojedinačnih društvenih aktera nadilazi ograničavajuće učinke lokalnih, nacionalnih, ali i međunarodnih institucija i aranžmana. Dok je početkom 20. stoljeća u društvenim znanostima bilo popularno prikazivati fizički ograničene migrantske kolonije i enklave koje brojni migranti gotovo nikada nisu napuštali, danas je sve popularnije prikazivati transnacionalno umrežene migrante koji nakon migracije i dalje nisu sedentarni i koji gotovo da $\mathrm{i}$ ne sudjeluju u lokalnim praksama i aktivnostima socijalno $\mathrm{i}$ etnički šarolikih populacija globalnih gradova. Njihovo vrijeme, angažman i lojalnost rezervirani su za prakse, aktivnosti i osobe koje se više ne nalaze u fizički bliskim i ograničenim prostorima, a s kojima intenzivno i svakodnevno komuniciraju, razmjenjuju sve oblike resursa i planiraju budućnost.

Usprkos sve većoj popularnosti koncepta transnacionalnoga socijalnog prostora i njegovu polaganom istiskivanju i zamjenjivanju koncepta transnacionalizma, u brojnim je slučajevima teško dokazati da su transnacionalne aktivnosti migranata toliko intenzivne, saturirane i ekskluzivne da prerastaju u transnacionalni socijalni prostor. S druge strane, u velikom broju slučajeva intenzivne transnacionalne aktivnosti i veze nadopunjuju isto tako intenzivne interetničke $i$ transetničke lokalne veze $i$ aktivnosti. $\mathrm{Uz}$ to, često je teško precizno analitički odvojiti vremenski kontinuirane i jasno strukturirane prakse od sporadičnih, manje intenzivnih, ali ipak društveno relevantnih aktivnosti. Autori većine studija o transnacionalizmu migranata, zbog ograničenja unutar samog istraživanja (nedovoljno novca, vremena, istraživača, pa tako i nemogućnosti plurilokalnog sinkroniziranog istraživanja), ne mogu pouzdano reći koliko transnacionalne aktivnosti čine integralni dio svakodnevice migranata, koliko su redovite i predvidljive, 
prema elementima Guarnizove definicije »središnjeg transnacionalizma« (Guarnizo, 2000, prema Levitt, 2001: 198), a da bi se mogle promatrati kao konstitutivni dio pretpostavljenog transnacionalnoga socijalnog prostora. Stoga je odabir analiziranja migrantskih transnacionalnih aktivnosti kao i eventualna procjena njihove saturacije i intenziteta puno pouzdaniji postupak od pretpostavljanja, pa zatim potvrđivanja ili odbacivanja postojanja transnacionalnih socijalnih prostora u određenom slučaju.

Zato smo odlučili prikazati i analizirati transnacionalne aktivnosti kineskih migranta u Hrvatskoj ${ }^{1}$ prema odabranim analitičkim dimenzijama transnacionalnih aktivnosti, uobičajenim u istraživanjima migrantskog transnacionalizma te ocijeniti objašnjavajuću moć i transferabilnost ustanovljenog analitičkog modela (dimenzija transnacionalnih aktivnosti), koji je do sada bio primjenjivan na druge migrantske skupine u drugim kontekstima i na empirijski slučaj kineskih migranata u Hrvatskoj. Sve veći broj kineskih migranata u Hrvatskoj, njihova prisutnost u svakodnevici i medijima, njihova djelatnost i prostorna mobilnost gotovo zahtijevaju istraživanje koje neće samo prikazati jednu migrantsku skupinu u tranzicijskom društvu nenaviklom na radnu i poduzetničku (i)migraciju. ${ }^{2}$ Socijalna stvarnost većine kineskih migranata traži istraživanje koje će njihovo djelovanje promatrati bez iskrivljujućih leća »metodološkog nacionalizma« (Wimmer i Glick Schiller, 2003) te koje će ih istraživati kroz prizmu transnacionalnih aktivnosti koje i jesu značajan dio socijalne stvarnosti kineskih migranata u većini zemalja (npr. Nyíri, 2002, 2007; Milutinović, 2005; Guerassimoff, 2003).

\section{Analitičke dimenzije transnacionalnih aktivnosti}

Transnacionalne aktivnosti čine značajan dio istraživanja migrantskog transnacionalizma, transnacionalnih socijalnih prostora i polja te se najčešće konceptualno razlikuju od oblika transnacionalnih identiteta. Tako, primjerice, Levitt i Glick Schiller (2004) razlikuju transnacionalne »načine bivanja« (ways of being) $\mathrm{i}$ »načine pripadanja« (ways of belonging), pri čemu se $\gg[n]$ ačini bivanja odnose na stvarne socijalne odnose i prakse u kojima pojedinci sudjeluju umjesto na identitete povezane s njihovim akcijama«

\footnotetext{
${ }^{1}$ Riječ je o dijelu istraživanja u okviru projekta $\gg$ Transnacionalne migracije - izazovi hrvatskom društvu« (076-0762385-2378) koji financira Ministarstvo znanosti, obrazovanja i sporta Republike Hrvatske.

2 Taj se oblik koristi kao pokušaj izbjegavanja terminologije svojstvene tzv. bipolarnom modelu teoretiziranja u migracijskim studijama (Brettell, 2008) pa se u ovom ra$\mathrm{du}$ uglavnom koristi termin »migrant«/»migracija« umjesto »emigrant«/»emigracija« ili »imigrant«/»imigracija«. Uz to, navedeni termini impliciraju metodološkonacionalističko pretpostavljanje trajnosti (i)migracije (usp. npr. Guarnizo, 1997).
} 
(Levitt i Glick Schiller, 2004: 1010). Slična je razdioba Al-Ali, Blacka i Kosera (2001b) između »transnacionalnih aktivnosti« i »transnacionalnih sposobnosti« (capabilities) pri čemu se aktivnosti »mogu promatrati i mjeriti«, dok sposobnosti predstavljaju »spremnost i mogućnost migrantskih skupina da se uključe u aktivnosti koje nadilaze državne granice«, uključujući i »stupanj do kojeg se pojedinci i zajednice identificiraju sa socijalnim, ekonomskim i političkim procesima u zemljama porijekla« (Al-Ali, Black i Koser, 2001b: 581). Većina autora implicitno ili eksplicitno uvažava preporuku Portesa, Guarniza i Landolt (1999) o istraživanju transnacionalizma kroz aktivnosti individualnih aktera kao osnovne jedinice analize.

U radovima o migrantskom transnacionalizmu upotrebljavaju se različite dimenzije $\mathrm{i}$ analitičke kategorije za istraživanje transnacionalnih aktivnosti koje se okvirno mogu podijeliti na sadržajne i formalne. Prema sadržaju, česta je podjela na ekonomske, političke i (socio)kulturne transnacionalne aktivnosti (usp. npr. Portes, Guarnizo i Landolt, 1999), mada se dio autora koristi i kategorijom »građansko-društvenih" (civil-societal) aktivnosti u koju se svrstava članstvo u zavičajnim društvima, sportskim udruženjima, sudjelovanje u dobrotvornim aktivnostima za zajednicu porijekla i sl. (Itzigsohn i dr., 1999). Iako se uobičajeno naglašava analitička narav podjele transnacionalnih aktivnosti na sadržajne sfere i njezina arbitrarnost, transnacionalne aktivnosti se razvrstavaju prema percipiranom primarnom cilju aktivnosti (npr. Itzigsohn $\mathrm{i}$ dr., 1999). ${ }^{3} \mathrm{~S}$ druge strane, socijalne transnacionalne aktivnosti rijetko se razmatraju kao zasebna kategorija, a iznimka je istraživanje Al-Ali, Blacka i Kosera (2001a) u kojem se, uz ekonomske, političke i kulturne aktivnosti, pojavljuje i spomenuta kategorija. Transnacionalne socijalne aktivnosti uz članstvo migranata u različitim udruženjima i klubovima, koje donekle odgovara »građansko-društvenim« aktivnostima Itzigsohna i dr. (1999), uključuju i socijalne doznake te održavanje kontakata s članovima obitelji i prijateljima posrednim i neposrednim putem.

Prema formi, uobičajena je podjela od nisko do visoko institucionaliziranih aktivnosti koja je primjenjiva na različite sadržajne sfere transnacionalnih aktivnosti. Tako, primjerice, Itzigsohn i dr. (1999) razlikuju između nisko institucionaliziranog slanja migrantskih doznaka u ekonomskoj sferi transnacionalnih aktivnosti do visoko institucionaliziranoga transnacional-

\footnotetext{
${ }^{3}$ Tako se, primjerice, sudjelovanje u zavičajnim društvima razmatra kao oblik transnacionalnih političkih aktivnosti (Landolt, Autler i Baires, 1999; Portes, 2001; Itzigsohn, 2000), sociokulturnih (Itzigsohn i Giorguli Saucedo, 2002; Portes, 2003), građansko-društvenih (Itzigsohn i dr., 1999) ili ekonomskih aktivnosti (Vertovec, 2004; Portes, Guarnizo i Haller, 2002), ovisno o pristupu autora, ciljevima istraživanja i konkretnom empirijskom primjeru.
} 
nog poduzetništva. S druge strane, Al-Ali, Black i Koser (2001a) razlikuju između individualnih, obiteljskih i transnacionalnih aktivnosti usmjerenih na zajednicu, koje primjerice u ekonomskoj sferi transnacionalnih aktivnosti variraju od slanja financijskih doznaka članovima uže obitelji (tzv. pojedinačne doznake) do tzv. kolektivnih doznaka, tj. doniranja novca za dobrotvorne projekte različitim organizacijama ili samoj državi porijekla. Dio autora razlikuje transnacionalne aktivnosti i prema geografskoj lokaciji i fokusu, tj. jesu li usmjerene prema državi porijekla ili državi primitka (usp. npr. Faist, 2004; Al-Ali, Black i Koser, 2001a), a navedena je podjela također primjenjiva na različite vrste transnacionalnih aktivnosti prema sadržaju. $^{4}$

Analitičke kategorije i dimenzije transnacionalnih aktivnosti ponekad se grupiraju u obuhvatnije kategorije. Jedan od primjera jest razlikovanje između »širokih« i »uskih« transnacionalnih aktivnosti Itzigsohna i dr. (1999), koji izdvajaju tri dimenzije transnacionalnih aktivnosti: »stupanj institucionalizacije različitih praksi, stupanj sudjelovanja pojedinaca $\mathrm{u}$ transnacionalnom polju i stupanj [fizičkog] kretanja pojedinaca unutar transnacionalnoga geografskog prostora« (Itzigsohn i dr., 1999: 317). Institucionalizacija transnacionalnih aktivnosti varira od niske do visoke, sudjelovanje od povremenog do stalnog, a fizičko kretanje varira od sporadičnog do redovitog. Transnacionalna aktivnost je »uska« ako na dvije od triju dimenzija odgovara visokoj institucionalizaciji ili stalnom sudjelovanju ili redovitom kretanju.

Drugi primjeri kategorizacije transnacionalnih aktivnosti uključuju Guarnizovu razdiobu na »središnji« i »prošireni transnacionalizam« prema intenzitetu transnacionalnih aktivnosti (Guarnizo, 2000, prema Levitt, 2001). »Središnji transnacionalizam« predstavljaju »aktivnosti koje: a) čine integralni dio uobičajenog (habitual) života pojedinca; b) poduzimaju se redovito; i c) imaju obrazac i stoga su donekle predvidljive. 'Prošireni transnacionalizam', s druge strane, uključuje migrante koji sudjeluju u povremenim transnacionalnim praksama, primjerice kao odgovor na političke krize i prirodne katastrofe« (Guarnizo, 2000, prema Levitt, 2001: 198). Navedeno približno odgovara podjeli na »široke« $\mathrm{i} » u s k e \ll$ transnacionalne aktivnosti (Itzigsohn i dr., 1999), naročito dimenzijama sudjelovanja i institucionalizacije. Dimenzija fizičkog kretanja u ovom slučaju nije eksplicitno formulirana, ali aktivnost može biti transnacionalna i onda kad ne uključuje fizičko kretanje.

\footnotetext{
${ }^{4}$ Usp. npr. dimenzije transnacionalnih političkih aktivnosti migranata u Østergaard-Nielsen (2003) ili empirijske tipove transnacionalnog poduzetništva u Zhou (2004) ili Morawska (2004).
} 
Guarnizovoj formalnoj razdiobi na »središnji« i »prošireni transnacionalizam« Levitt (2001: 198) dodaje i drugu, sadržajnu dimenziju, tj. razlikovanje transnacionalnih aktivnosti prema dosegu na »selektivne« $\mathrm{i}$ »obuhvatne«, ovisno o ekstenzivnosti sadržajnih sfera transnacionalnih aktivnosti u kojima pojedinci sudjeluju. Dvije dimenzije su neovisne pa tako ista osoba može sudjelovati u središnjim transnacionalnim aktivnostima $u$ jednoj sferi (selektivne aktivnosti), a u drugim sferama samo povremeno (»prošireni transnacionalizam«) (Levitt, 2001: 198).

Iako spomenute kategorije imaju stanovitu heurističnu vrijednost, njihovo bi nekritičko primjenjivanje moglo reproducirati slučaj analitički upitne dihotomije »transnacionalizma odozdo« i »transnacionalizma odozgo« (Guarnizo i Smith, 1998), koja se u literaturi o migrantskom transnacionalizmu primjenjuje na različite načine i s različitim pretpostavkama. Tako se, primjerice, razdioba »širokih« i »uskih« transnacionalnih aktivnosti (Itzigsohn i dr., 1999) ponekad koristi kao sinonimna podjeli na »prošireni« i »središnji transnacionalizam« (Guarnizo 2000, prema Levitt, 2001) zanemarujući originalni kompozitni karakter kategorija. ${ }^{5} \mathrm{~S}$ druge strane, Vertovec (2009) nastoji identificirati »tipologije« migrantskog transnacionalizma te izdvaja i »središnje« i »proširene« aktivnosti, definirajući ih kao aktivnosti koje imaju obrazac, predvidljive su i odvijaju se u jednoj sferi društvenog života (Vertovec, 2009: 18), odnosno »povremene prakse u širem nizu sfera« (Vertovec, 2009: 18), ne razlikujući pritom dvije dimenzije aktivnosti, tj. intenzitet i doseg. Analitički je uputnije zadržati se na osnovnim dimenzijama transnacionalnih aktivnosti, umjesto da ih se nekonzistentno kategorizira kao »široke«, »uske«, »središnje«, »proširene« i sl. Stoga se $u$ istraživanju transnacionalnih aktivnosti kineskih migranata u Hrvatskoj koriste dimenzije poput sadržaja aktivnosti, intenziteta tj. frekventnosti aktivnosti, stupnja institucionalizacije i sl., a druge se kategorije koriste gdje je to primjenjivo uz uvažavanje specifičnosti empirijskog slučaja i provedenog istraživanja. S obzirom na brojnost radova koji istražuju raznovrsne aspekte migrantskih transnacionalnih aktivnosti svaki je izbor dimenzija i, naročito, analitičkih kategorija selektivan, iako smo nastojali obuhvatiti dimenzije koje su relativno zastupljene i primjenjivane $u$ istraživanjima različitih autora u različitim kontekstima i koje su adekvatne za konkretan empirijski primjer.

\footnotetext{
${ }^{5}$ Npr. u Østergaard-Nielsen (2003). Usp. i korištenje »širokog« i »uskog« po uzoru na Itzigsohna i dr. (1999) kao sinonima za veličinu transnacionalnih migrantskih mreža (Vertovec, 2001: 19) i nedovoljno razjašnjenu interpretaciju u Vertovec (2009). Naročito je problematično posljedično kategoriziranje transnacionalnih aktivnosti u tipove transnacionalizma bez jasnih kriterija za empirijsko utvrđivanje rasprostranjenosti i dosega fenomena.
} 


\section{Istraživanje}

Istraživanje je provedeno u razdoblju od listopada 2009. godine do siječnja 2010. i predvidjelo je strateško korištenje metode polustrukturiranih intervjua. ${ }^{6}$ Intervjuiranje je teklo u dvjema fazama. U eksplorativnoj fazi intervjuiranja provedeno je pet intervjua s ekspertima za kinesku migrantsku skupinu $^{7}$ koji su opisivali svoje spoznaje o (trans)nacionalnim aktivnostima kineskih migranata i njihovoj svakodnevici u Hrvatskoj. Eksperti su imali značajnu ulogu u istraživanju i kao tzv. »gatekeepers« (usp. Bloor i Wood, 2006) za pristup drugim kineskim migrantima te su dali kontakte za nastavak istraživanja, kao i informacije za eventualnu prilagodbu istraživačkog pristupa i predviđenih pitanja.

U drugoj fazi istraživanja provedeno je deset polustrukturiranih intervjua s pripadnicima kineske migrantske skupine. Primijenjeno uzorkovanje kombiniralo je metodu "grude snijega« (snowball) s načelom maksimalne varijacije (usp. Miles i Huberman, 1994) čime se nastojala postići zastupljenost različitih iskustava sugovornika prema spolu, dobi, stručnoj spremi i zanimanju kao i određeni stupanj poopćivosti tvrdnji o socijalnoj stvarnosti kineskih migranata. Intervjuirane su tri sugovornice i sedam sugovornika. Svi intervjuirani sugovornici pripadnici su prve generacije kineskih migranata u Hrvatskoj, što odgovara relativno nedavnom migracijskom toku iz Narodne Republike Kine u Hrvatsku.

Teme o kojima se razgovaralo $\mathrm{u}$ intervjuima obuhvaćale su aspekte prekogranične (posredne) komunikacije i razmjene, kao i aktivnosti sugovornika u Hrvatskoj ili drugim zemljama, organizirane oko povijesti (i) migracije, svakodnevice i budućih planova sugovornika, s tim da je redoslijed i konkretan sadržaj pitanja ovisio o iskustvima sugovornika, kao i o njihovoj spremnosti da govore o određenim temama. Sugovornicima su postavljana otvorena pitanja i omogućena im je maksimalna sloboda u izražavanju o temama iz vlastitoga migracijskog i postmigracijskog iskustva,

\footnotetext{
${ }^{6}$ Termin polustrukturirani ili polustandardizirani intervju različito se koristi za opisivanje intervjua s točno određenim redoslijedom (otvorenih) pitanja koja se uvijek postavljaju na isti način (usp. Arthur i Nazroo, 2003) ili čak s kombinacijom otvorenih i zatvorenih pitanja (usp. Gillham, 2004), ali i fleksibilnijeg pristupa intervjuiranju sa zadanim okvirnim temama razgovora (usp. Bloor i Wood, 2006; Hopf, 2004) bez propisanog redoslijeda i striktnog protokola. Vrsta intervjua korištena u ovom istraživanju odgovara potonjem značenju.

${ }^{7}$ Ekspertima se smatraju osobe koje imaju uvid u dio empirijske stvarnosti koji je nedostupan istraživaču, bez obzira na njihovo formalno obrazovanje ili stručnost u određenom specijaliziranom području (usp. Bogner, Littig i Menz, 2002). Eksperti su bili Kinezi i nekinezi, a među njima su zaposlenici u kineskim malim i većim obrtima, poznavaoci kineske kulture i jezika i poznavaoci velikog broja kineskih migranata u Hrvatskoj. Navedeni su podaci djelomično izmijenjeni, tj. poopćeni kako bi se zaštitio identitet sugovornika/ca.
} 
kao i iz iskustva članova njihovih obitelji ili prijatelja, koja su smatrali relevantnima. ${ }^{8}$

Svi su intervjui provedeni u Zagrebu, mjestu najveće koncentracije kineskih migranata u Hrvatskoj. Većina intervjua zabilježena je diktafonom uz pristanak sugovornika, a svim je sugovornicima zajamčena privatnost, povjerljivost i anonimnost. Intervjui se navode na sljedeći način: e17: 012, pri čemu prvi broj označava sugovornika/cu, ${ }^{9}$ a drugi broj označava paragraf(e) tekstualnog segmenta unutar transkripta. Ekspertni intervjui dodatno su označeni slovom »e«. Iako je analiza provođena na originalnim (doslovnim) transkriptima, navodi sugovornika u daljnjem su tekstu prilagođeni hrvatskom standardu prema Seidmanovoj (2006) preporuci, ${ }^{10} \mathrm{a}$ citati iz intervjua provedenih na engleskom jeziku, prevedeni su na hrvatski. Prije prikaza i analize transnacionalnih aktivnosti kineskih migranata $\mathrm{u}$ Hrvatskoj, uvodno se kratko prikazuju podaci o useljavanju, djelatnostima i sociodemografskim karakteristikama kineske migrantske skupine u Hrvatskoj. Pregled koji slijedi oslanja se na malobrojne dostupne izvore i na informacije prikupljene intervjuima s kineskim sugovornicima i ekspertima.

\section{Kineski migranti u Hrvatskoj}

Prema podacima Ministarstva unutarnjih poslova Republike Hrvatske, 23. svibnja 2008. godine u Hrvatskoj je boravilo 713 državljana Narodne Republike Kine, koja je zauzela 8. mjesto na popisu država čiji su državljani najbrojniji s reguliranim boravkom u Republici Hrvatskoj (Horvat, 2008). Od navedenih 713 državljana Kine u Hrvatskoj 2008. godine, 415 osoba imalo je odobren privremeni boravak, 122 stalni boravak, a 176 osoba boravilo je u Hrvatskoj s poslovnim dozvolama (Horvat, 2008). Prema podacima Državnog zavoda za statistiku, u 2009. godini u Hrvatsku je uselilo

\footnotetext{
${ }^{8} \mathrm{~S}$ obzirom na nepoznavanje kineskog jezika od strane istraživača ili hrvatskog od strane dijela kineskih sugovornika i sugovornica, neki su intervjui vođeni na engleskom jeziku.

${ }^{9}$ Iako se zamjenjivanje osoba brojevima može činiti dehumanizirajućim, taj je način označavanja i navođenja intervjua, uz zaštitu identiteta sugovornika, odabran zbog veće preglednosti i lakšeg snalaženja u MAXQDA programu za obradu podataka, a nastojalo se izbjeći i davanje stereotipnih etničkih pseudonima sugovornicima. Brojevi su dodjeljivani slučajnim odabirom, a variraju od 1 do $42 \mathrm{~s}$ obzirom da je sâmo istraživanje uključilo pripadnike drugih migrantskih skupina, uz kinesku.

${ }_{10} \gg$ Neki bi mogli tvrditi da istraživači ne bi trebali mijenjati usmeni govor sudionika [istraživanja] kad ga predstavljaju kao pisani dokument. No, mislim da su zahtjevi za realizmom usmenog govora uravnoteženi istraživačevom obvezom za održavanjem dostojanstva sudionika prilikom pismenog predstavljanja njegovog ili njezinoga usmenog govora, osim ako istraživač ne planira semantičku analizu ili je predmet intervjua jezični razvoj sudionika« (Seidman, 2006: 122).
} 
77 osoba, državljana NR Kine, što je najveći broj u razdoblju od 2005. godine. U istom je razdoblju (2005. - 2009.), prema navedenim podacima, iz Hrvatske iselila jedna osoba s kineskim državljanstvom (Priopćenje Državnog zavoda za statistiku, broj 7.1.2., 26. svibnja 2010.). Navedeni se službeni podaci razlikuju od procjena iz provedenih intervjua s kineskim sugovornicima i stručnjacima, prema kojima se broj Kineza u Hrvatskoj kreće od 2000 do 3000. Mogući razlozi diskrepancije između službenih podataka i procjena sugovornika uključuju neadekvatnost prikupljanja službenih podataka, $\mathrm{tj}$. neprilagođenost mobilnosti migranata, neuključivanje zahtjeva za boravak koji su u proceduri, nepostojanje podataka o neotkrivenim ilegalnim prelascima granica ili ostanku u Hrvatskoj nakon isteka vize, neuključivanje kineskih migranata s državljanstvima drugih država i sl.

Kineski migranti u Hrvatsku uglavnom useljavaju nakon 2000. godine, a njihovu je (i)migraciju okvirno moguće podijeliti u tri faze (Podgorelec i Kuti, 2005). U prvoj fazi osamdesetih i početkom devedesetih godina (i) migriraju diplomati, studenti na razmjeni i poslovni ljudi zaposleni u predstavništvima hongkonških tvrtki u Zagrebu. Druga faza započinje sredinom devedesetih kad u Hrvatsku pristiže brojčano značajnija skupina kineskih migranata, poduzetnika koji otvaraju poduzeća i restorane, na početku samo u većim gradovima. Treća i najznačajnija faza useljavanja kineskih migranata u Hrvatsku počinje nakon 2000. godine. U toj fazi u Hrvatsku useljavaju kineski migranti koji su prethodno boravili u susjednim državama (primjerice Mađarskoj, Srbiji, BiH), Rumunjskoj, ali i u državama poput Austrije, Njemačke i Italije. Dio kineskih migranata useljava i izravno iz NR Kine, a prema informacijama iz provedenih intervjua s kineskim sugovornicima, to su nedavni (i)migranti, koji dijelom pristižu putem spajanja obitelji. Većina je kineskih migranata u Hrvatskoj porijeklom iz pokrajine Zhejiang u južnoj Kini, koju se opisuje kao tipičnu emigracijsku pokrajinu.

Kineski migranti, prema podacima iz provedenih ekspertnih intervjua, uglavnom borave u Zagrebu. Unatoč koncentraciji u glavnom gradu, prisutni su u prostoru cijele Hrvatske, a prema opisu kineskog eksperta, u svakom mjestu s više od 5000 stanovnika postoji kineski dućan. ${ }^{11}$ Najrasprostranjenije djelatnosti kineskih migranata u Republici Hrvatskoj su trgovina (veleprodaja i maloprodaja) i ugostiteljstvo. Manji dio kineskih

\footnotetext{
${ }_{11} \gg$ Mogu reći da su, (...) osim u Zagrebu, u drugim dijelovima Hrvatske - to su Kinezi koji se bave maloprodajom, odnosno, drže svoje maloprodajne dućane. (...) I oni su rekli da skoro svako mjesto, ako ima više od 5000 stanovnika, tamo sigurno već postoji kineski dućan« (e17: 010). Spomenuti je podatak sličan podatku o kineskim migrantima u Mađarskoj prema kojem u svakom mjestu s više od 2000 stanovnika postoji kineski dućan (Nyíri, 2002).
} 
migranata u Hrvatskoj radi u predstavništvima kineskih tvrtki u Zagrebu na području telekomunikacija, u tvrtkama koje se bave uvozom i izvozom te $\mathrm{u}$ drugim nekineskim tvrtkama koje uglavnom posluju s NR Kinom ili kineskim migrantima u Hrvatskoj. Također, u Hrvatskoj djeluje nekoliko liječnika tradicionalne kineske medicine, prevoditelja, sudskih tumača i drugih konzultanata, koji pružaju usluge kineskim migrantima.

Prema informacijama iz provedenih intervjua, kinesku migrantsku skupinu u Hrvatskoj uglavnom čine mlađe, radno sposobne osobe, iako postoji i starija populacija roditelja. Kineski su migranti prilikom dolaska u Hrvatsku uglavnom u bračnom statusu, no neki upoznaju partnerice/partnere u Hrvatskoj ili tijekom poslovnih putovanja u Kinu. S druge strane, prema informacijama iz hrvatskih medija i osobnim spoznajama istraživača, postoji i donekle značajan broj brakova kineskih državljana i državljanki s hrvatskim državljanima/kama nekinezima, s obzirom na relativnu malobrojnost kineske migrantske skupine u Hrvatskoj. Obitelji kineskih migranata u Hrvatskoj često su brojne, proširene i do sto članova, sa snažnim obiteljskim vezama koje pogoduju lančanom obrascu (i)migracije. Politika jednog djeteta u NR Kini primjenjuje se od 1979. godine pa je moguće pretpostaviti da se nije u tolikoj mjeri odrazila na veličinu kineskih obitelji u Hrvatskoj s obzirom na to da je, prema informacijama iz provedenih intervjua, većina kineskih migranata u Hrvatskoj starija od 30 godina. Iako postoji određeni broj kineske djece u hrvatskim školama, djeca kineskih migranata uglavnom se školuju u Kini, naročito na osnovnoškolskoj razini. ${ }^{12}$

U dijelu koji slijedi prikazuju se i opisuju transnacionalne aktivnosti kineskih migranata u Hrvatskoj uz navođenje primjera iz provedenih intervjua s kineskim sugovornicima i ekspertima, a potom se analizira primjenjivost ustanovljenoga analitičkog modela dimenzija transnacionalnih aktivnosti na empirijski slučaj kineskih migranata u Hrvatskoj, u skladu s osnovnim ciljem rada.

\section{Transnacionalne aktivnosti kineskih migranata u Hrvatskoj}

Sugovornici su opisivali različite sadržajne sfere transnacionalnih aktivnosti, oslanjajući se dijelom na vlastita iskustva, ali i komentirajući transnacionalne aktivnosti kineskih migranata u Hrvatskoj općenito. Opisane transnacionalne aktivnosti su prema sadržaju razvrstane u ekonomske, političke i kulturne, u skladu s analitičkim kategorijama kakve se uobičajeno primjenjuju u radovima o migrantskom transnacionalizmu. Spomenutim je

\footnotetext{
${ }^{12}$ Jedan od razloga, prema nekineskim ekspertima, jest kompleksnost kineskog jezika, koji nekvalificirani roditelji teško prenose - napose pismo. Također, unutar sâme Kine relativno je često da roditelji rade u jednoj pokrajini, dok se djeca školuju u drugoj.
} 
kategorijama dodana i kategorija socijalnih transnacionalnih aktivnosti koja je uključila posredne i neposredne socijalne kontakte s članovima obitelji i prijateljima u zemlji porijekla ili trećim zemljama. U slučajevima u kojima su primjenjive, u analizi se koriste i druge dimenzije, primjerice stupanj formalne institucionalizacije aktivnosti, sadržajna ekstenzivnost aktivnosti (selektivne i obuhvatne transnacionalne aktivnosti /Levitt, 2001/) te intenzitet aktivnosti (središnje i proširene transnacionalne aktivnosti /Guarnizo, 2000, prema Levitt, 2001/). S obzirom da u literaturi o transnacionalnim aktivnostima migranata dominiraju opisne kategorije (primjerice, stupanj sudjelovanja u pojedinim transnacionalnim aktivnostima prema Itzigsohnu i dr. /1999/ ili intenzitet aktivnosti prema elementima Guarnizove definicije »središnjeg transnacionalizma«/2000, prema Levitt, 2001: 198/), za pojedine su sadržajne dimenzije aktivnosti primijenjene i pomoćne analitičke kategorije frekventnosti i sezonalnosti aktivnosti (usp. Bell i Ward, 2000). ${ }^{13}$ Transnacionalna fizička mobilnost uglavnom se ne razmatra kao posebna analitička kategorija, tj. kao odrednica »širokih« odnosno »uskih« aktivnosti (Itzigsohn i dr., 1999), već kao zasebna aktivnost za koju se također nastoji ustanoviti frekventnost, geografska relacija ili pripadanje pojedinoj sferi aktivnosti prema sadržaju. Najprije se prikazuju transnacionalne aktivnosti kineskih migranata u Hrvatskoj podijeljene prema sadržajnim sferama, potom komentira primjenjivost izdvojenih analitičkih dimenzija i kategorija na konkretan empirijski slučaj.

\section{1. Transnacionalne ekonomske aktivnosti}

$\mathrm{S}$ obzirom na to da znatan dio kineskih migranata u Hrvatskoj predstavljaju mali i srednji poduzetnici, u sadržaju provedenih intervjua zastupljeni su opisi ekonomskih transnacionalnih aktivnosti prema sadržaju aktivnosti, naročito opisi oblika i strategija transnacionalnog poduzetništva. ${ }^{14}$ Prema opi-

\footnotetext{
${ }^{13}$ Bell i Ward (2000) koriste kategorije trajnosti, frekventnosti i sezonalnosti u istraživanju odlika »privremene mobilnosti« u odnosu na »trajnu migraciju«. Osim u razmatranju fizičke mobilnosti/migracije, spomenute se analitičke kategorije mogu upotrijebiti u istraživanju drugih transnacionalnih aktivnosti (primjerice, frekventnost i sezonalnost transnacionalne posredne komunikacije ili slanja migrantskih doznaka).

${ }^{14}$ Istraživanja transnacionalnog poduzetništva izdvajaju različite empirijske tipove, koji se razlikuju i po stupnju formalne institucionalizacije te prema geografskom fokusu, tj. usmjerenosti aktivnosti. Primjerice, Zhou (2004) razlikuje transnacionalna poduzeća za financijske usluge, za različite kulturne usluge, mikropoduzeća koja u državama porijekla osnivaju migranti povratnici, proizvodne pogone u jednoj ili više država te poduzeća za uvoz ili izvoz robe, uključujući i neformalne tipove trgovine. Većina je aktivnosti kineskih transnacionalnih poduzetnika u Hrvatskoj bliska potonjem tipu te uključuju redovite kontakte s dobavljačima iz Kine ili drugih država.
} 
su kineskog eksperta, postoje dvije strategije transnacionalnog poduzetništva kineskih migranata u Hrvatskoj - širenje poduzeća u drugu državu, ili $\mathrm{u}$ nekoliko država, te zatvaranje poduzeća u jednoj državi i seljenje u drugu:

Neki [su] proširili svoje poslove, ostali još u drugim zemljama (...), ali proširili u Hrvatsku. A neki su došli i potpuno odbacili prijašnji posao $i$ [počeli] tu u Hrvatskoj kao nova baza. (e17: 008) ${ }^{15}$

Kineski poduzetnici koji šire svoje transnacionalne ekonomske aktivnosti iz jedne države u drugu, prema opisu kineskog eksperta, često povjeravaju posao članovima obitelji u drugim državama, tj. fizička mobilnost i fleksibilnost kineskih poduzetnika je pospješena transnacionalnim obiteljskim vezama:

(...) većina kineskih državljana koji su u Hrvatskoj, za njih je tipično da se povezuju s rodbinom, tu je najbliže. Tako da možda njihove sestre ili braća [vode] posao u Rumunjskoj (...), a oni sami dolaze u Hrvatsku i stvaraju novo tržište. (e17: 008)

Prema izjavi istog eksperta, u većini slučajeva transnacionalne poduzetničke obitelji kineskih migranata ne posjeduju formalno povezana transnacionalna poduzeća (e17: 009), tj. podružnice istog poduzeća u više država, nego poduzeća povezana čvrstim obiteljskim vezama. Funkcioniranje kineskih transnacionalnih obiteljskih poduzeća zasnovano je na međusobnom povjerenju članova obitelji, što potkrjepljuje i primjer poduzetničke transnacionalne obitelji sugovornika:

[moj me stric] zaposlio kao menadžera. (...) Radio sam izvještaje jer je moj stric u Mađarskoj i trebao je nekoga kome može vjerovati da bude u Rumunjskoj pa je odabrao mene. (34: 015)

Geografski fokus transnacionalnih poduzetničkih aktivnosti kineskih migranata u Hrvatskoj nije nužno na relaciji država useljenja - država porijekla, nego može uključivati druge države, ovisno o poslovnim i obiteljskim vezama, ali i o geografskoj udaljenosti alternativnih centara kineske trgovine (Italija, Mađarska) koja smanjuje transakcijske troškove poduzetnika. Tako, primjerice, dio kineskih poduzetnika u Hrvatskoj uvozi kinesku robu iz Italije:

Neki [kineski poduzetnici] uvoze iz Italije, to je bliže i ima manje poreza za plaćati [nego iz Kine]. Carina je jako skupa. (20: 031)

${ }^{15}$ Dvije su strategije transnacionalnog poduzetništva vidljive i u opisu transnacionalne poduzetničke obitelji jednog sugovornika: »Moj najstariji stric vodi sjedište u Mađarskoj, mlađi stric vodi podružnicu u Srbiji, a moj je otac prije također radio za njega [najstarijeg strica]. On je vodio posao u Bosni, ali je sada odlučio započeti nešto samostalno i zato je došao ovdje u Hrvatsku« (34: 020). Slične strategije opisuju i drugi autori razmatrajući transnacionalne ekonomske aktivnosti kineskih migranata u ovom dijelu Europe (npr. Milutinović, 2005; Nyíri, 2002, 2007). 
Dio kineskih poduzetnika, vlasnika ugostiteljskih objekata, dobavlja robu iz Mađarske, a prema opisima sugovornika dio kineskih migranata u Hrvatskoj ima dozvole za boravak ili državljanstva drugih europskih zemalja što im znatno olakšava fizičku mobilnost i nabavku robe. Primjerice:

Neki Kinezi imaju osobne iskaznice iz Austrije ili Njemačke i oni mogu ići tamo lakše. Samo se odvezu i idu tamo. I onda mogu jednostavnije kupovati. (30: 054)

Unatoč ovim primjerima, prema podacima iz provedenih intervjua, kineska se roba u Hrvatsku uglavnom uvozi izravno iz Kine, što zahtijeva i relativno frekventnu fizičku mobilnost poduzetnika, kao u poduzetničkoj obitelji sugovornika:

[Istraživačica] Pričaj mi o svom ocu, stricu i ostatku obitelji i njihovu poslu. Putuju li oni u Kinu? Da, putuju jer (...) se bavimo uvozom i izvozom tako da trebaju putovati u Kinu barem dvaput ili triput godišnje zato što trebaju odabrati $i$ kupiti stvari iz Kine $i$ onda ih uvesti ovdje. (34: 023$)^{16}$

Dio kineskih sugovornika opisuje relativno česte poslovne boravke u Kini koji uključuju i posjete članovima obitelji, kompenzirajući troškove putovanja kroz kombinaciju transnacionalnih aktivnosti u ekonomskoj i socijalnoj sadržajnoj sferi. Primjerice:

Često idem u Kinu. (...) Idem u Kinu službeno dva do tri puta godišnje pa onda uvijek odvojim dva dana, jedan, da budem s [mamom]. A koliko ostajete u Kini? Dva, dva do tri tjedna. Poslovno pa par dana kod mame? Poslovno, da. Dva-tri tjedna. Kad dođem pa onda jedan dandva pa onda poslije, prije nego što idem, pa opet dva, tri, [dana], ovisno o poslu. Ako rješavam sve glatko, onda ostanem duže. (31: 029) ${ }^{17}$

\footnotetext{
${ }^{16}$ Ovaj primjer uključuje relativno visok stupanj formalne institucionalizacije aktivnosti, stalno sudjelovanje u aktivnostima i relativno redovito fizičko kretanje te bi se uvjetno mogao okarakterizirati kao oblik »uskih« transnacionalnih aktivnosti (Itzigsohn i dr., 1999), iako u navedenom radu nedostaju jasnije smjernice za kategorizaciju aktivnosti prema pojedinoj dimenziji, a primjena očito ovisi o specifičnom kontekstu. Tako npr. transnacionalna fizička mobilnost poduzetnika u Kinu može biti redovita, ali ne i česta, za razliku od, primjerice, mobilnosti u europske države. S druge strane, prema Portesu, Guarnizu i Landolt (1999), minimalna definicija migrantskog transnacionalizma u smislu fizičke mobilnosti uključuje putovanja u zemlju porijekla nekoliko puta godišnje. Riječ je o uvjetu prilagođenom američkom geografskom kontekstu koji, u slučaju relacije RH - Kina također može biti primjenjiv, ali ne i u slučaju relacije Hrvatska - okolne države, koje su također uključene u transnacionalne aktivnosti kineskih migranata.

${ }^{17}$ Spomenuti primjer upućuje na mogućnost primjene dimenzije sadržajne ekstenzivnosti, tj. podjele između »selektivnih« i »obuhvatnih« transnacionalnih aktivnosti (Levitt, 2001) prema broju uključenih sfera aktivnosti. Ako je kombinacija dviju sadržajnih sfera aktivnosti dovoljna, ovaj bi se primjer mogao okarakterizirati kao »obuhvatne« aktivnosti.
} 
Uz oblike transnacionalnog poduzetništva, literatura o transnacionalnim aktivnostima migranata uobičajeno uključuje migrantske doznake kao tipičan primjer nisko (formalno)institucionaliziranih transnacionalnih ekonomskih aktivnosti (Itzigsohn i dr., 1999; Al-Ali, Black i Koser, 2001a; Landolt, 2001). Financijske doznake migranata manje su zastupljene u sadržaju provedenih intervjua, iako je moguće pretpostaviti da je posrijedi relativno zastupljen oblik transnacionalnih aktivnosti unutar kineske migrantske skupine, naročito unutar prostorno razdvojenih transnacionalnih užih obitelji, npr. između supružnika ili roditelja i djece. Primjerice:

Pomažete li im financijski? Da. Moji im roditelji pomažu jer (...) je to tradicija u Kini da su djeca odgovorna za starije ljude, roditelje. (34: 054)

Slanje novca ponekad ima karakter posudbe, naročito u okviru transnacionalnih poduzetničkih obitelji u kojima si članovi obitelji međusobno pomažu prilikom uspostavljanja posla, situacijsko je i u nekim primjerima ne uključuje relaciju Hrvatska - Kina, nego Hrvatska - treće zemlje ili Kina - Hrvatska. Na primjer:

(...) kad trenutno fali neki novac, oni [uža obitelj u Kini i SAD-u] pomažu, ali ja isto vraćam čim mogu, ali to vrlo rijetko, vrlo rijetko. (31: 039) ${ }^{18}$

U razmatranju ekonomske sfere aktivnosti bitno je istaknuti da postoje i visoko institucionalizirane prekogranične ekonomske aktivnosti dijela kineskih migranata, zaposlenika multinacionalnih poduzeća u Hrvatskoj, koje nisu posebnim predmetom analize u ovom radu s obzirom na to da pripadaju »transnacionalizmu odozgo« (Guarnizo i Smith, 1998) ili obliku multinacionalnih ekonomskih aktivnosti prema Portesovom (2001, 2003) preciznijem razgraničenju prekograničnih aktivnosti na internacionalne, multinacionalne i transnacionalne.

Razmatranje transnacionalnih ekonomskih aktivnosti kineskih migranata u Hrvatskoj upućuje na nekoliko problema prilikom primjene izdvojenih analitičkih dimenzija i kategorija. Primjeri transnacionalnih obiteljskih poduzetničkih aktivnosti indiciraju poteškoće prilikom analitičkog razdvajanja aktivnosti prema sadržaju, konkretno u ekonomskoj, nasuprot socijalnoj sferi transnacionalnih aktivnosti, koja uključuje posjete članova obitelji i prijatelja kao i posrednu komunikaciju preko granica nacija-država, jer je u nekim primjerima teško izdvojiti primarnu motivaciju aktivnosti. U slučaju aktivnosti kineskih transnacionalnih poduzetničkih obitelji postoji problem

\footnotetext{
${ }^{18} \mathrm{~S}$ obzirom na to da je riječ o aktivnosti koja je nisko institucionalizirana, povremena $\mathrm{i}$ uglavnom ne uključuje fizičku mobilnost, moguće ju je svrstati u oblik »širokih« transnacionalnih aktivnosti (Itzigsohn i dr. 1999).
} 
i s određivanjem stupnja formalne institucionalizacije aktivnosti, jer je u nekim primjerima riječ o neformalnim, ali visoko funkcionalnim transnacionalnim poduzećima koja spajaju poduzetničke aktivnosti članova obitelji u nekoliko država, a ne o podružnicama istoga transnacionalnog poduzeća, iako u provedenim intervjuima ima i takvih primjera. S druge strane, neki primjeri pokazuju potencijalnu primjenjivost dimenzije sadržajne ekstenzivnosti, tj. razdiobe na »selektivne« $\mathrm{i}$ »obuhvatne« aktivnosti (Levitt, 2001) iako u navedenom radu nedostaju jasni kriteriji za primjenu kategorija.

Naposljetku, primjeri iz provedenih intervjua s kineskim migrantima u Hrvatskoj ilustriraju i poteškoće s nekritičkim primjenjivanjem bipolarnoga geografskog fokusa transnacionalnih aktivnosti podijeljenih između »zemlje porijekla« i »zemlje primitka«, kakav je uobičajen u radovima o migrantskom transnacionalizmu, transnacionalnim socijalnim prostorima $\mathrm{i}$ poljima jer transnacionalne aktivnosti mogu uključivati nekoliko zemalja i nisu nužno orijentirane na »zemlju porijekla«, što pokazuju primjeri aktivnosti transnacionalnih poduzetnika, ali i slanja doznaka koje ne teku nužno iz zemlje »useljenja« u »zemlju porijekla« nego i obratno i/ili uključuju treće lokacije. ${ }^{19}$

\section{2. Transnacionalne socijalne aktivnosti}

Uvođenje socijalne sfere transnacionalnih aktivnosti, tj. razdvajanje uobičajene kategorije »sociokulturnih« transnacionalnih aktivnosti pokazalo se analitički korisnim pristupom s obzirom na to da su aktivnosti poput međusobnog posjećivanja članova obitelji i prijatelja te, naročito, posredne komunikacije relativno zastupljene među kineskim migrantima u Hrvatskoj. Većina kineskih sugovornika ima članove uže obitelji u Kini ili trećim zemljama s kojima su u relativno frekventnom posrednom kontaktu, na tjednoj bazi ili češće. Na primjer:

(...) jedno smo se vrijeme dopisivali, ali u zadnje vrijeme se ipak čujemo telefonom, vrlo često, da. Koliko često se recimo čujete s mamom? Dva, tri puta tjedno. Tjedno? Da. A sa sestrom u Americi? Isto tako. (31: 019)

Kontaktiraš li s nekim u Kini? Naravno, koristim Skype [osmijeh]. (...) Koliko često? Koliko često? Hm, ok, koristim Internet $i$ imamo neki softver poput msn-a, ali je iz Kine. Zove se $Q Q$ i komuniciramo međusobno skoro svaki dan. Ja preferiram telefonske pozive pa koris-

${ }^{19}$ Usp. istraživanje V. Mazzucato (2010) koja je došla do sličnih zaključaka istražujući tokove doznaka na relaciji ruralnih područja Gane, grada Accre i Amsterdama. 
tim Skype. Koliko često? Mislim možda tjedno. Koliko dugo? Možda dva ili tri sata, ako razgovaramo, ako smo sretni. (30: 052)

Trajanje razgovora s članovima obitelji, prema opisima kineskih sugovorni$\mathrm{ka}$, traje od dvadesetak minuta do dva ili tri sata. S druge strane, nekineski ekspert opisuje intenzivnu posrednu komunikaciju kineskih kolega u ugostiteljskom objektu s prijateljima i članovima obitelji u drugim zemljama koja je ponekad grupna:

Koliko vremena provode u komunikaciji preko Interneta? Pa nekad pet sati, nekad pola sata. Dnevno? Dnevno, da. Nekad mogu, ako ih se skupi više, njih šest, $i$ onda obično tog prijatelja nazovu ili tu djevojku ili nekoga, mogu i deset sati provoditi (...) - jedan je dva sata, pa jedan priča sat vremena, pa opet drugoga nazovu, sve to u jednoj noći (...) jer se oni druže međusobno. (e5: 031)

Uz održavanje posrednih kontakata, socijalna sfera transnacionalnih aktivnosti uključila je i fizičku mobilnost kineskih migranata, tj. posjećivanje članova obitelji ili prijatelja. Sugovornici koji su nedavno uselili u Hrvatsku nisu posjećivali članove obitelji u Narodnoj Republici Kini, ali svi u vrijeme provođenja intervjua ističu da planiraju sljedeće godine. Frekventnost putovanja u Kinu drugog dijela sugovornika varira od dva do tri puta godišnje, jednom godišnje, svakih par godina ili rjeđe. Kao što je već istaknuto, dio sugovornika putuje u Kinu zbog poslovnih razloga te tom prilikom posjećuju članove obitelji, ponekad i u drugoj pokrajini, kompenzirajući trošak putovanja i geografsku udaljenost na relaciji $\mathrm{Hr}-$ vatska - Kina:

Jesi li bio doma u posjetu? Prošle godine (...) Bio sam vodič, prevoditelj $i$ sve. (...) Onda sam bio doma tri dana, nije baš puno, ali planiram iduće godine opet, a sad trebam skupiti novac. To nije jeftino. I nije blizu, to je sedam tisuća kilometara. (20: 015)

Fizička mobilnost sugovornika u europske zemlje frekventnija je od mobilnosti na relaciji Hrvatska - Kina. Dio sugovornika spominje članove obitelji u susjednim zemljama koje posjećuju nekoliko puta godišnje ili češće, naročito ako je riječ o kombinaciji poslovnih i obiteljskih razloga. Primjerice:

Zapravo sam se upravo vratio iz Mađarske jer sam jučer bio $u$ Mađarskoj. Imao sam sastanak s nekim. Za posao? S mojim stricem, da. A u druge zemlje putujem jednom mjesečno, otprilike. Ovisi o poslu jer (...) tijekom poslovne sezone možemo putovati češće. (34: 022)

Iz prethodnih je primjera moguće izvesti nekoliko zaključaka o primjenjivosti izdvojenih dimenzija i kategorija. Ponajprije, uobičajeno razmatranje transnacionalnih aktivnosti prema sadržaju bez posebno izdvojene 
socijalne sfere u konkretnom bi slučaju dovelo do zanemarivanja značajnog dijela socijalne stvarnosti kineskih migranata u Hrvatskoj, s obzirom na relativnu rasprostranjenost neposrednih $i$, naročito, posrednih kontakata $\mathrm{s}$ članovima obitelji i prijateljima u Kini, ali i drugim državama, uz upotrebu suvremenih komunikacijskih medija. Primjena dimenzija i, posljedično, kategorija Itzigsohna i dr. (1999) je naročito problematična u razmatranju održavanja transnacionalnih kontakata posrednim putem, jer navedena aktivnost nije formalno institucionalizirana i ne uključuje fizičko kretanje, unatoč relativno frekventnom i često intenzivnom sudjelovanju. Prema kriterijima Itzigsohna i dr. (1999), ova bi aktivnost bila okarakterizirana kao »široka«, a ne kao »uska«. Stoga je za razmatranje socijalne sfere transnacionalnih aktivnosti adekvatnija Guarnizova distinkcija između »središnjih « i »proširenih« aktivnosti (Guarnizo, 2000, prema Levitt, 2001), iako ni ona nije neproblematična na što se upućuje i u zaključku. ${ }^{20}$

Naposljetku, opisane transnacionalne aktivnosti i u ovoj sadržajnoj sferi upućuju na potrebu za revidiranjem istraživanja transnacionalnih aktivnosti kao podijeljenih između »zemlje porijekla« i »zemlje useljenja« prema geografskom fokusu s obzirom na to da sugovornici navode posredne i neposredne socijalne kontakte s članovima obitelji i prijateljima u više od deset različitih država. Istraživanje koje bi se ograničilo na relaciju Hrvatska - Kina zanemarilo bi značajan dio empirijskih relevantnih transnacionalnih aktivnosti i u slučaju socijalnih aktivnosti kineskih migranata.

\section{3. Transnacionalne kulturne aktivnosti}

$\mathrm{U}$ literaturi o migrantskom transnacionalizmu, kulturna sfera aktivnosti uključuje sudjelovanje u kulturnim manifestacijama s ciljem promicanja kulture zemlje porijekla, posjećivanje različitih nastupa umjetnika iz zemlje porijekla, proslave nacionalnih praznika i blagdana (usp. npr. Al-Ali, Black i Koser, 2001a; Portes, Guarnizo i Landolt, 1999), praćenje medija iz zemlje porijekla (Itzigsohn i dr., 1999) i sl. Od spomenutih aktivnosti, među kineskim migrantima u Hrvatskoj najzastupljenije je praćenje kineskih medija. Dio sugovornika prati kineske medije dostupne na Internetu, dok drugi dio posjeduje satelitske antene preko kojih mogu pratiti nekoliko kineskih televizijskih programa. Prema opisu sugovornika, koji upućuje i na simboličku vrijednost te vrste transnacionalne aktivnosti:

\footnotetext{
${ }^{20}$ Umjesto primjene dihotomnih kategorija, empirijskom je slučaju primjerenije uvođenje dodatnih kategorija, tj. razlikovanje između intenziteta, frekventnosti i sezonalnosti transnacionalnih aktivnosti, koje su i korištene u analizi provedenih intervjua.
} 
Imamo televiziju, imamo kineski program CCTV (...) Možemo vidjeti vijesti iz Kine. (...) Internet uglavnom koriste mladi ljudi. Znaš, Kinezima i dalje nedostaje domovina, nevezano uz to koliko dugo borave u drugoj zemlji. (30: 053)

Praćenje medija u nekim je slučajevima svakodnevno, unatoč vremenskoj razlici između Hrvatske i Kine. Prema opisu sugovornice:

Doma imamo kinesku televiziju, ima četiri programa. Imamo satelitsku $i$ onda svako jutro gledamo vijesti. (...) Ili navečer, zato što je osam sati [vremenske] razlike. Navečer dođem doma, onda je u Kini jutro i onda gledamo televiziju. (28: 017)

Kineski tiskani mediji iz Kine, ili u nekim slučajevima iz drugih europskih zemalja, također cirkuliraju među kineskim migrantima u Hrvatskoj, iako s određenim vremenskim pomakom:

(...) dolazi dosta ljudi, Kineza, ima ih puno, i oni donesu novine pa ih onda pitam imaju li nešto za čitati i onda mi daju nešto, ali je to sve obično već staro [smijeh]. (31: 044)

Za razliku od, primjerice, Mađarske u kojoj se tiska nekoliko kineskih novina (usp. Nyíri, 2007) u Hrvatskoj za sada ne postoje časopisi na kineskom jeziku tiskani u Hrvatskoj.

Sugovornici spominju i cirkuliranje DVD-ova s novim kineskim filmovima među kineskim migrantima u Hrvatskoj, a jedan sugovornik opisuje nabavljanje knjiga preko člana obitelji:

(...) kad netko dolazi, ja njega zamolim da kupi neke knjige. Stric ima godišnji odmor, uvijek ide u Kinu na odmor, onda kupi neke knjige pa donese tu. (20: 019)

Unutar kulturne sfere aktivnosti bitno je istaknuti i periodične proslave kineskih nacionalnih praznika i blagdana koje se održavaju u Zagrebu, najčešće u organizaciji ambasade Narodne Republike Kine u kojima su sudjelovali neki sugovornici, a koje uključuju i povremena gostovanja kineskih umjetnika iz drugih europskih država, primjerice Austrije. S druge strane, nije riječ o aktivnosti »malih«, spontanih i neinstitucionalnih aktera, nego o obliku »transnacionalizma odozgo" (Guarnizo i Smith, 1998) ili čak internacionalnih aktivnosti prema Portesovoj $(2001,2003)$ tipologiji prekograničnih aktivnosti.

Spomenute transnacionalne kulturne aktivnosti kineskih migranata $\mathrm{u}$ Hrvatskoj ponovno upućuju na problematičnu raspodjelu između »uskih« i »širokih" aktivnosti, tj. primjenu pojedinih dimenzija. Naime, praćenje kineskih televizijskih programa, koje je najrasprostranjenije prema podacima iz provedenih intervjua, može biti često (dimenzija sudjelovanja), ali ne uključuje fizičko kretanje. I u ovom je primjeru aktivnosti problematična 
primjena dimenzije (formalne) institucionalizacije. U slučaju kineskih migranata u Hrvatskoj, ne može se govoriti o (formalno)institucionaliziranoj aktivnosti iz perspektive migranata, iako praćenje medija predstavlja značajan dio svakodnevice. Dosljednom primjenom dimenzija Itzigsohna i dr. (1999) praćenje medija bilo bi uvršteno u »široke«, a ne »uske« aktivnosti, iako je u nekim primjerima iz provedenih intervjua riječ o relativno frekventnoj i intenzivnoj aktivnosti. Stoga je i u ovom primjeru prikladnija primjena drugih analitičkih kategorija (npr. frekventnost aktivnosti, intenzitet i sl.).

\section{4. Transnacionalne političke aktivnosti}

Posljednja, politička sfera transnacionalnih aktivnosti u literaturi o migrantskom transnacionalizmu najčešće uključuje aktivnosti poput članstva u zavičajnim udruženjima, donacija zajednici porijekla, članstva u političkim strankama, sudjelovanja u izbornim kampanjama i izborima u zemlji porijekla i sl. Većina spomenutih aktivnosti ima samo ograničenu primjenjivost u političkom kontekstu Narodne Republike Kine. Uz to, kineska je migrantska skupina relativno kratko prisutna u Hrvatskoj pa ne iznenađuje relativna podzastupljenost transnacionalnih političkih aktivnosti u opisima kineskih migranata, primjerice zavičajnog organiziranja. Kineski ekspert navodi i druge razloge iz kojih u Hrvatskoj nedostaju oblici organizacija kakvi postoje u drugim europskim zemljama:

Ja mislim u Hrvatskoj, kao prvo, da su to (...) relativno mladi migranti, a ne kao u drugim zapadnim zemljama u kojima možda već postoji nekoliko generacija Kineza. Ovdje su sve nedavni [migranti] $i$ to većinom dolaze tek nakon 2000. godine (...) Ovdje još ne postoji takva tradicija da se organiziraju u udruge kao u drugim zemljama. A druga stvar je, po mom mišljenju, da su ti ljudi, koji su došli u Hrvatsku, s relativno nižim obrazovanjem $i$ oni, možda, ne misle toliko na rad u udrugama. Oni su orijentirani na vlastiti posao, (...) kako zaraditi. (e17: 018)

Slično je (u posljednjem segmentu) i objašnjenje nekineskog eksperta prema kojemu kineski migranti u Hrvatskoj zbog intenzivnog radnog tempa nemaju vremena za udruživanje ili neki drugi oblik političkog angažmana (e5, bilješke istraživačice). Moguće je pretpostaviti da transnacionalne političke aktivnosti kineskih migranata u Hrvatskoj za sada imaju karakter "proširenih" transnacionalnih aktivnosti koje su situacijske i nastaju eventualno »kao odgovor na političke krize i prirodne katastrofe« (Guarnizo, 2000, prema Levitt, 2001: 198). S druge strane, slučaj kineske migrantske skupine u Mađarskoj upućuje na osnivanje više udruga s različitim stupnjevima (transnacionalnog) političkog angažmana (usp. Nyíri, 2005, 2007). 
S obzirom na slično regionalno porijeklo kineskih migranata, umreženost, kontekst primitka, a u nekim slučajevima i izravne migracijske tokove iz Mađarske, u Hrvatskoj je moguće očekivati razvoj sličnih udruženja s vremenom, tj. duljim boravkom i većom brojnošću pripadnika kineske migrantske skupine.

\section{Zaključak}

U prethodnim su poglavljima opisane transnacionalne aktivnosti kineske migrantske skupine u Hrvatskoj. Opisi iz provedenih intervjua ukazuju na rasprostranjenost ekonomskih aktivnosti, naročito oblika transnacionalnog poduzetništva te na neformalne socijalne aktivnosti u privatnoj sferi, naročito posrednu komunikaciju i održavanje kontakata s članovima obitelji i prijateljima u Kini ili trećim zemljama. Transnacionalne kulturne aktivnosti su manje rasprostranjene, naročito u obliku formalnih aktivnosti kakve se opisuju u istraživanjima drugih migrantskih skupina, poput gostovanja umjetnika iz države porijekla, organiziranja kulturnih manifestacija i sl., dok su političke aktivnosti, čak i one usmjerene na kineske migrante u Hrvatskoj, tj. stvaranje relevantnih udruga, za sada rijetke. Oblici transnacionalnog javnog djelovanja i interakcije $s$ institucijama države porijekla ograničeni su na kontakte s dobavljačima robe u Kini ili drugim državama, tj. umreženost u kineske ekonomske tokove. Istovremeno, rasprostranjeni oblici etničkog poduzetništva kineskih migranata u Hrvatskoj predstavljaju oblik javne prisutnosti i vidljivosti ove migrantske skupine, a s vremenom je moguće očekivati i druge oblike javnog djelovanja u političkoj i kulturnoj sferi, kakvi su zabilježeni u drugim državama u kojima je kineska migrantska skupina brojnija i duže prisutna.

Prikazane transnacionalne aktivnosti kineskih migranata u Hrvatskoj ukazuju i na različite poteškoće prilikom primjene simplificiranih analitičkih kategorija kakve se pojavljuju u radovima o migrantskom transnacional$i z m u$. Čak je i naizgled jednostavna podjela prema sadržaju transnacionalnih aktivnosti u nekim slučajevima problematična s obzirom na to da autori $\mathrm{u}$ relevantnoj literaturi nekonzistentno uvrštavaju pojedine aktivnosti u tipove prema sadržaju i s obzirom na to da je u pojedinim empirijskim slučajevima teško odrediti primarnu sferu aktivnosti, što pokazuju primjeri kineskih transnacionalnih poduzetničkih obitelji. S druge strane, zasebno razmatranje socijalne sfere aktivnosti, umjesto raznolikih sociokulturnih aktivnosti (Portes, Guarnizo i Landolt, 1999) pokazalo se empirijski relevantnim obogaćenjem u slučaju transnacionalnih aktivnosti kineskih migranata u Hrvatskoj.

Guarnizova dihotomna razdioba na »središnji« i »prošireni transnacionalizam« (Guarnizo, 2000, prema Levitt, 2001) pokazala se problema- 
tičnom na konkretnom empirijskom primjeru s obzirom na to da postoje brojne aktivnosti koje nisu u potpunosti »središnje«, ali nisu ni posve »proširene« prema elementima autorove definicije. Stoga je uputnije istraživati transnacionalne aktivnosti s pomoću preciznijih analitičkih kategorija poput frekventnosti ili sezonalnosti, koje su se pokazale korisnima ne samo u razmatranju transnacionalne fizičke mobilnosti, nego i održavanja posrednih kontakata u socijalnoj ili npr. ekonomskoj sferi. Tako se istodobno može izbjeći opasnost od prenaglašavanja dosega fenomena, što je jedna od kritika »ranim« radovima o migrantskom transnacionalizmu (usp. npr. Portes, 2003), i nekritičkog pretpostavljanja postojanja transnacionalnih socijalnih prostora. ${ }^{21}$

Prethodno spomenuto donekle vrijedi i za pokušaj primjene kategorizacije Itzigsohna i dr. (1999) koja, iako originalno zamišljena kao niz kontinuuma, često završava u dihotomnoj podjeli aktivnosti na »uske« i »široke«. Svrstavanje pojedinih aktivnosti prema predloženim dimenzijama je u većoj ili manjoj mjeri problematično, ovisno o sadržajnoj sferi aktivnosti. Tako su, primjerice, dimenzije fizičke mobilnosti i stupnja (formalne) institucionalizacije $u$ manjoj mjeri primjenjive u socijalnoj sferi aktivnosti, koja uključuje posredno održavanje kontakata koje nije formalno institucionalizirano, ne uključuje fizičku mobilnost, a može uključivati stalno sudjelovanje te bi se u nekim empirijskim slučajevima moglo okarakterizirati kao oblik »središnjih« aktivnosti prema Guarnizu.

Dodatni problem s kategorizacijom Itzigsohna i dr. (1999) jest opisno određivanje krajnjih polova kontinuumâ jer nije posve jasno npr. koliko često jest »redovito《 na dimenziji fizičkog kretanja i mogu li se u tu kategoriju uvrstiti sezonska putovanja migranata. Sličan je problem i s određivanjem sadržajne ekstenzivnosti aktivnosti prema Levitt (2001), tj. uvrštavanjem aktivnosti u »selektivne« ili »obuhvatne« s obzirom na to da nije jasno koliki broj sadržajnih sfera treba biti »pokriven« djelovanjem migranata da bi ih se sa sigurnošću moglo smatrati obuhvatnim aktivnostima. ${ }^{22}$ Zbog svih se spomenutih razloga primjena analitičkih kategorija i di-

${ }^{21}$ Do sličnog je zaključka, ne navodeći eksplicitno radove citirane u ovom radu došla i Morawska (2004). Umjesto podjele na »sporadični« i »redoviti transnacionalizam«, autorica razlikuje između kategorija »sporadičnog«, »redovitog« i »intenzivno redovitog«, a navedena bi podjela mogla biti relevantna i u slučaju transnacionalnih aktivnosti kineskih migranata u Hrvatskoj.

${ }^{22} \mathrm{~S}$ obzirom na analitički pristup, u većini je slučajeva bilo nemoguće procjenjivati doseg, tj. sadržajnu ekstenzivnost na razini pojedine opisane aktivnosti jer je većina kodiranih tekstualnih segmenata opisivala selektivnu aktivnost. Na razini sadržaja cjelokupnih intervjua, moguće je zaključiti da većina sugovornika češće sudjeluje u jednoj sferi transnacionalnih aktivnosti (selektivne aktivnosti), dok je sudjelovanje u drugim sferama povremeno. 
menzija za istraživanje transnacionalnih aktivnosti treba prilagoditi konkretnom empirijskom slučaju, umjesto nekritičkog posuđivanja i nekonzistentne upotrebe, koja često završava reifikacijom tipova transnacionalizma i prenaglašavanjem fenomena. Naposljetku, primjer transnacionalnih aktivnosti kineskih migranata u Hrvatskoj upućuje i na potrebu za revidiranjem često isključivoga bipolarnog geografskog fokusa aktivnosti podijeljenih između »zemlje porijekla« i »zemlje primitka« s obzirom da opisane aktivnosti kineske migrantske skupine uključuju više zemalja i nisu nužno orijentirane na »zemlju porijekla«.

Bitno je istaknuti i neka ograničenja istraživanja. Idealno bi bilo istraživanje transnacionalnih aktivnosti u više lokaliteta, po mogućnosti u nekoliko faza kako bi se mogla procijeniti njihova trajnost i dinamika, ali to nije bilo moguće s obzirom na vremenska i financijska ograničenja istraživanja. Naposljetku, opisani primjeri uglavnom uključuju tzv. »objektivne« dimenzije transnacionalnih aktivnosti tj. koncentrirani su na opažljive aktivnosti koje je lakše ustanoviti, opisati i interpretirati (usp. Levitt, DeWind i Vertovec, 2003: 571). S druge strane, postoje i »subjektivne« dimenzije transnacionalnih aktivnosti koje uključuju »maštu i emocije koje se duboko osjećaju, ali ne i izražavaju otvoreno« (Levitt, DeWind i Vertovec, 2003: 571), a buduća će istraživanja tek trebati obuhvatiti subjektivne dimenzije transnacionalnih aktivnosti kineskih migranata u Hrvatskoj. Unatoč tomu, »objektivne« dimenzije poput stupnja institucionalizacije, frekventnosti aktivnosti, geografskog fokusa i sl. uz opreznu i preciznu upotrebu mogu pospješiti istraživanje transnacionalnih aktivnosti i indicirati njihovu saturiranost, što ima izravne implikacije za operacionaliziranje i ustanovljavanje transnacionalnih socijalnih prostora u budućim istraživanjima.

\section{LITERATURA}

Al-Ali, Nadje, Black, Richard i Koser, Khalid (2001a). »Refugees and Transnationalism: The Experience of Bosnians and Eritreans in Europe«, Journal of Ethnic and Migration Studies, 27 (4): 615-634. doi:10.1080/13691830120090412

Al-Ali, Nadje, Black, Richard i Koser, Khalid (2001b). »The Limits to 'Transnationalism': Bosnian and Eritrean Refugees in Europe as Emerging Transnational Communities«, Ethnic and Racial Studies, 24 (4): 578-600. doi:10.1080/01419870120049798

Arthur, Sue i Nazroo, James (2003). »Designing Fieldwork Strategies and Materials«, u: Jane Ritchie i Jane Lewis (ur.). Qualitative Research Practice: A Guide for Social Science Students and Researchers. London: Sage Publications, str. 109-137.

Bell, Martin i Ward, Gary (2000). »Comparing Temporary Mobility with Permanent Migration«, Tourism Geographies, 2 (1): 87-107. doi:10.1080/146166800363466 
Bloor, Michael i Wood, Fiona (2006). Keywords in Qualitative Methods: A Vocabulary of Research Concepts. London: Sage Publications.

Bogner, Alexander, Littig, Beate i Menz, Wolfgang (ur.) (2002). Das Experteninterview: Theorie, Methode, Anwendung. Opladen: Leske \& Budrich.

Božić, Saša (2004). »Nacionalizam - nacija, 'transnacionalizam' - 'transnacija': mogućnosti terminološkog usklađivanja«, Revija za sociologiju, 35 (3-4): 187-203.

Brettell, Caroline B. (2008). »Theorizing Migration in Anthropology: The Social Construction of Networks, Identities, Communities, and Globalscapes«, u: Caroline B. Brettell i James F. Hollifield (ur.). Migration Theory: Talking across Disciplines. 2nd ed. London i New York: Routledge, str. 113-159.

Faist, Thomas (2004). »The Border-Crossing Expansion of Social Space: Concepts, Questions and Topics«, u: Thomas Faist i Eyüp Özveren (ur.). Transnational Social Spaces: Agents, Networks and Institutions. Aldershot: Ashgate, str. 1-34.

Gillham, Bill (2004). The Research Interview. London and New York: Continuum.

Guarnizo, Luis Eduardo (1997). »The Emergence of a Transnational Social Formation and the Mirage of Return Migration among Dominican Transmigrants«, Identities, 4 (2): 281-322. doi:10.1080/1070289X.1997.9962591

Guarnizo, Luis Eduardo i Smith, Michael Peter (1998). »The Locations of Transnationalism«, u: Michael Peter Smith i Luis Eduardo Guarnizo (ur.). Transnationalism from Below. New Brunswick: Transaction Publishers, str. 3-34 (Comparative Urban and Community Research V6).

Guerassimoff, Carine (2003). »The New Chinese Migrants in France«, International Migration, 41 (3): 135-154. doi:10.1111/1468-2435.00244

Hopf, Christel (2004). »Qualitative Interviews: An Overview«, u: Uwe Flick, Ernst von Kardorff i Ines Steinke (ur.). A Companion to Qualitative Research. London: Sage Publications, str. 203-208.

Horvat, Dražen (2008). »Tko nam dolazi u Hrvatsku«, u: Međunarodna konferencija Useljenička politika u funkciji razvoja hrvatskoga gospodarstva [Zbornik radova]. Zagreb: Hrvatska gospodarska komora, str. 29-34.

Itzigsohn, José (2000). »Immigration and the Boundaries of Citizenship: The Institutions of Immigrants' Political Transnationalism«, International Migration Review, 34 (4): 1126-1154.

Itzigsohn, José, Dore Cabral, Carlos, Hernández Medina, Esther i Vázquez, Obed (1999). »Mapping Dominican Transnationalism: Narrow and Broad Transnational Practices«, Ethnic and Racial Studies, 22 (2): 316-339. doi:10.1080/ 014198799329503

Itzigsohn, José i Giorguli Saucedo, Silvia (2002). »Immigrant Incorporation and Sociocultural Transnationalism«, International Migration Review, 36 (3): 766798. doi:10.1111/j.1747-7379.2002.tb00104.x

Landolt, Patricia (2001). »Salvadoran Economic Transnationalism: Embedded Strategies for Household Maintenance, Immigrant Incorporation, and Entrepreneurial Expansion«, Global Networks, 1 (3): 217-241. doi:10.1111/1471-0374.00014

Landolt, Patricia, Autler, Lilian i Baires, Sonia (1999). »From Hermano Lejano to Hermano Mayor: The Dialectics of Salvadoran Transnationalism«, Ethnic and Racial Studies, 22 (2): 290-315. doi:10.1080/014198799329495 
Levitt, Peggy (2001). »Transnational Migration: Taking Stock and Future Directions«, Global Networks, 1 (3): 195-216. doi:10.1111/1471-0374.00013

Levitt, Peggy, DeWind, Josh i Vertovec, Steven (2003). »International Perspectives on Transnational Migration: An Introduction«, International Migration Review, 37 (3): 565-575. doi:10.1111/j.1747-7379.2003.tb00150.x

Levitt, Peggy i Glick Schiller, Nina (2004). »Conceptualizing Simultaneity: A Transnational Social Field Perspective on Society«, International Migration Review, 38 (3): 1002-1039. doi:10.1111/j.1747-7379.2004.tb00227.x

Mazzucato, Valentina (2010). »Operationalising Transnational Migrant Networks through a Simultaneous Matched Sample Methodology«, u: Rainer Bauböck i Thomas Faist (ur.). Diaspora and Transnationalism: Concepts, Theories and Methods. Amsterdam: Amsterdam University Press, str. 205-226.

Miles, Matthew B. i Huberman, Michael, A. (1994). Qualitative Data Analysis: An Expanded Sourcebook. 2nd ed. Thousand Oaks: Sage.

Milutinović, Svetlana (2005). »Kineski transnacionalni preduzetnici u Budimpešti i Beogradu: u potrazi za tržištima tranzicionih ekonomija«, Sociologija, 47 (2): $143-160$.

Morawska, Ewa (2004). »Exploring Diversity in Immigrant Assimilation und Transnationalism: Poles and Russian Jews in Philadelphia«, International Migration Review, 38 (4): 1372-1412. doi:10.1111/j.1747-7379.2004.tb00241.x

Nyíri, Pál (2002). »Globalising Chinese Migration: New Spaces, New Meanings«, Migracijske $i$ etničke teme, 18 (1): 23-39.

Nyíri, Pál (2005). „Chinese in Hungary«, u: Melvin Ember, Carol R. Ember i Ian Skoggard (ur.). Encyclopedia of Diasporas: Immigrant and Refugee Cultures Around the World. Volume 2: Diaspora Communities. New York: Kluwer Academic/Plenum Publishers, str. 664-672.

Nyíri, Pál (2007). Chinese in Eastern Europe and Russia: A Middleman Minority in a Transnational Era. London and New York: Routledge.

Østergaard-Nielsen, Eva (2003). »The Politics of Migrants' Transnational Political Practices«, International Migration Review, 37 (3): 760-786. doi:10.1111/ j.1747-7379.2003.tb00157.x

Podgorelec, Sonja i Kuti, Simona (2005). »Ethnic Entrepreneurship in Croatia - A Life Story«, [izlaganje na skupu] The Chances of the Second Generation in Families of Ethnic Entrepreneurs: Intergenerational and Gender Aspects of Quality of Life Processes, Brač, 2-4 June 2005.

Portes, Alejandro (2001). »Introduction: The Debates and Significance of Immigrant Transnationalism«, Global Networks, 1 (3): 181-193. doi:10.1111/1471-0374.00012

Portes, Alejandro (2003). »Conclusion: Theoretical Convergencies and Empirical Evidence in the Study of Immigrant Transnationalism«, International Migration Review, 37 (3): 874-892. doi:10.1111/j.1747-7379.2003.tb00161.x

Portes, Alejandro, Guarnizo, Luis Eduardo i Haller, William J. (2002). »Transnational Entrepreneurs: An Alternative Form of Immigrant Economic Adaptation«, American Sociological Review, 67 (2): 278-298. doi:10.2307/3088896

Portes, Alejandro, Guarnizo, Luis E. i Landolt, Patricia (1999). »The Study of Transnationalism: Pitfalls and Promise of an Emergent Research Field«, Ethnic and Racial Studies, 22 (2): 217-237. doi:10.1080/014198799329468 
Pries, Ludger (2001). »The Approach of Transnational Social Spaces: Responding to New Configurations of the Social and the Spatial«, u: Ludger Pries (ur.). New Transnational Social Spaces: International Migration and Transnational Companies in the Early Twenty-first Century. London: Routledge, str. 3-33.

Pries, Ludger (2008). »Transnational Societal Spaces: Which Units of Analysis, Reference and Measurement?«, u: Ludger Pries (ur.). Rethinking Transnationalism: The Meso-link of Organisations. London: Routledge, str. 1-20.

Priopćenje Državnog zavoda za statistiku, broj 7.1.2., 26. svibnja 2010. Zagreb: Državni zavod za statistiku.

Seidman, Irving (2006). Interviewing as Qualitative Research: A Guide for Researches in Education and the Social Sciences. 3rd ed. New York and London: Teachers College Press, Columbia University.

Vertovec, Steven (2001). »Transnational Social Formations: Towards Conceptual Cross-Fertilization«, Paper presented at Workshop on Transnational Migration: Comparative Perspectives, Princeton University, June 30 - July 1, 2001, www. transcomm.ox.ac.uk/working\%20papers/Vertovec2.pdf (21. 07. 2011.).

Vertovec, Steven (2004). »Migrant Transnationalism and Modes of Transformation«, International Migration Review, 38 (3): 970-1001. doi:10.1111/j.1747-7379.2004. tb00226.x

Vertovec, Steven (2009). Transnationalism. London and New York: Routledge.

Wimmer, Andreas i Glick Schiller, Nina (2003). »Methodological Nationalism, the Social Sciences, and the Study of Migration: An Essay in Historical Epistemology«, International Migration Review, 37 (3): 576-610. doi:10.1111/j.1747-7379.2003. tb00151.x

Zhou, Min (2004). »Revisiting Ethnic Entrepreneurship: Convergencies, Controversies, and Conceptual Advancements«, International Migration Review, 38 (3): 1040-1074. doi:10.1111/j.1747-7379.2004.tb00228.x

\title{
Analytical Dimensions for the Research of Transnational Activities: An Example of Chinese Migrants in Croatia
}

\author{
Simona KUTI \\ Institute for Migration and Ethnic Studies, Zagreb, Croatia \\ simona.kuti@imin.hr \\ Saša BOŽıć \\ Department of Sociology, University of Zadar, Croatia \\ sbozic@unizd.hr
}

The concept of transnational social spaces is slowly replacing the concept of transnationalism, which is being criticised as a failed term, due to its conceptual ambiguity, inability to determine the boundaries of the phenomenon that is being 
dealt with, etc. However, only some cases of migrant transnational ties grow into transnational social spaces, which are very difficult to investigate with limited resources and a limited number of researchers since they require continuous and synchronized observation of daily practices in several international localities. Therefore, the selection of analysis of migrant transnational activities as well as any assessment of their saturation and intensity is a more reliable procedure than assuming and then confirming or discarding the existence of transnational social spaces in a particular case. This paper presents the results of the research of transnational activities of Chinese migrants in Croatia using semi-structured interviews. Dimensions and analytical categories for researching transnational activities are selected from the research on migrant transnationalism, and the results are structured according to the content of activities (economic, social, cultural and political transnational activities). The explanatory power and transferability of the established analytical model, which has so far been used in the research of other migrant groups in other contexts, is assessed through the presentation of transnational activities of Chinese migrants in Croatia.

Key words: dimensions of transnational activities, transnationalism, Chinese migrants, Croatia 